a guide to periodicals and is arranged by regions and countries, each regional section being followed by a subject index. There is an author index at the end of the volume. The author intends to update the bibliography in the future and would appreciate receiving relevant new citations and notification of any errors found. Copies, $\$ 5.00$ each, may be ordered from the Bureau of Business and Economic Research, Georgia State University, 33 Gilmer Street, S.E., Atlanta, Georgia 30303 .

\title{
Royal Anthropological Institute of Great Britain and Ireland: Art Panel
}

THE 1970 autumn programme of the Art Panel of the Royal Anthropological Institute was devoted to African studies on the theme of tools, materials, and techniques, and the ways in which they influence form and style in art. The papers included: Nigerian textiles today (Mrs. N. F. Stanfield); Housing in Zaria (F. W. Schwerdtfeger); Factors affecting style in Ashanti art (M. D. McLeod); Iconography of some modern Fanti monuments (W. J. Argyle). A seminar to discuss the materials presented was held at the end of the series.

\section{'Southern African Studies'}

THe collection of the papers presented at the symposium arranged by the African Studies Association of the United Kingdom in September 1969 , has been published as a special edition of the Association's Bulletin. (Southern African Studies; edited by M. R. Kettle and R. P. Moss. Published by the African Studies Association of the United Kingdom. I24 pp.)

The first and longest section consists of the papers themselves, grouped under the following headings: Archaeology, History, Language, Law, Politics, Agriculture, Geography, Anthropology, and Economics. In most groups contributions from university teachers in Afrikaans-speaking and English-speaking universities and from universities in Britain, contain surveys and assessments of work being done on South African topics in their respective disciplines and types of university. The second section consists of notes on the discussions at the symposium itself. Lists of those who presented papers, of those who attended the symposium, and a name index based on the papers and the discussion are given.

Members of the A.S.A.U.K. receive this symposium report direct. Others may obtain copies on application to the Hon. Secretary, A.S.A.U.K. c/o Centre of West African Studies, University of Birmingham, P.O. Box ${ }_{3} \sigma_{3}$, Birmingham Is. Price $f \mathrm{r}$, including postage.

\section{'Tiv Proverbs as a Means of Social Control', by Harold M. Bergsma (Africa, xl, April 1970, pp. I 5 -63)}

WE have received the following comment from Professor Paul Bohannan:

'In Harold M. Bergsma's article, I believe there is a mistake in his rendering of a proverb (if such it be) that he claims Captain Downes collected. As Bergsma quotes it (I have not looked up the original in Downes) the statement reads ' Kwase $u$ ikom senen mger, $m$ ta ibalegh a kar a sen. Ijua nor senen mger $m$ tsue $m$ kuve'. Bergsma is quite correct that Captain Downes's translation bears no relationship to the original. But I believe that Bergsma himself has made an error. I may be wrong because he has not published tones (sensibly enough). He translates ijua nor in the second sentence as 'Penis elephant' or 'hippo'. If the tones are right, he is correct. But if the tones are a little different ijua nor means an erect penis, which would make the second sentence in his ' proverb' read ' Erect penis flowing downwards on the water, I retrieve and cover it '. Note that I have translated kiwe differently, too. It is true that Abraham's Dictionary gives 'embrace' as the meaning of $k$ woe; it is also true that 'cover' is a better translation in most contexts. Retranslated this way, the passage is reduced to a fairly normal Tiv chant, carried out at the time that an akombo is washed in 